\title{
Tourist Behavioral Intentions and Festival Quality: The Case of Kaohsiung's Lantern Festival
}

\author{
Chen-Yi Wu \\ Rooms Division Management, Kenting Maldives Hot Spring Hotel, Shengbei Road, Hengchun \\ Township, Kenting, Taiwan \\ chenyiwu0918qq@gmail.com
}

\begin{abstract}
The purpose of this research was to examine a comprehensive model of revisiting intention of festival. More specifically, the research tested a model linking festival authenticity to festival quality, satisfaction, to a given festival. Using convenience sampling method, empirical data was collected at the Kaohsiung 's Lantern Festival in Kaohsiung. A sample of 301 domestic tourists who attended the festival was surveyed. Applying structural equation modeling, the findings showed that perceived quality was found to have the direct effect on perceived satisfaction. Satisfaction had the direct effect on revisiting Intention.
\end{abstract}

Keywords: festival; revisiting intention; festival quality; festival satisfaction

\section{INTRODUCTION}

Festivals are an essential feature of cultural tourism (Chang, 2006 and Getz, 2008). In fact, they have become an important part of a destination's portfolio of tourism products (Getz, 2008). Festivals, as one of the fastest growing types of events, have increased with regard to number, diversity and popularity since the 1980s (Getz, 2008, Gursoy et al., 2006 and Yang et al., 2011). A festival is defined as "the celebration of a specific theme to which the public is invited for a limited period of time. This celebration can be held annually or less frequently, and includes single events" (Grappi \& Montanari, 2011, p. 1129).

Festivals are recognized as an effective strategy for host destinations to gain several potential economic, social and cultural benefits (Grappi \& Montanari, 2011). They can be seen as a strategy to achieve economic development, a way to create positive image, a stimulator of tourism demand, an expander of tourist seasons, a means to enhance the life and pride of local people, and a way to reinforce social cohesion within the communities (Getz, 2008, Grappi and Montanari, 2011, Lee, 2014, Lee et al., 2007,Saleh and Ryan, 1993 and Weber and Ali-Knight, 2012).In recent years, the celebration activities of various folk-custom festivals have been getting more and more attention from the citizens in Taiwan. Festivities throughout the whole island are traditionally accompanied by loud and brightly colored firework displays. Among these activities, the firework displays during Taiwan's Lantern Festival in Kaohsiung harbor is one of the largest festivals in Taiwan each year.

One of the main ways to achieve success is to build revisiting intention in attendees (Lee, 2014, Wu et al., 2014 and Yang et al., 2011). Indeed, customer loyalty is widely recognized as a major element of business success. Various researchers had contributed to develop predictors of attendee revisiting intention in the festival literature. For instance, researchers had explored the effects of festival authenticity (e.g. Castéran and Roederer, 2013 and Shen, 2014), festival quality (e.g. Wong et al., 2014 and Wu et al., 2014), festival value (e.g. Lee et al., 2007 and Yang et al., 2011), and satisfaction with festival (e.g. Grappi and Montanari, 2011, Lee, 2014 and Mason and Paggiaro, 2012) on revisiting intention to festival. In addition, it is widely accepted that trust leads to revisiting intention (Lee and Back, 2008 and Wang et al., 2014). Therefore, in order to better understand which factors may lead to attendee revisiting intention, the current research proposed a comprehensive model to test the effects of festival quality, satisfaction and revisiting intention to a given festival. Furthermore, the research examined the relationships among the predictors. The findings provide information for widening the festival literature. 


\section{LITERATURE REVIEW}

\subsection{Festival Quality}

Perceived quality refers to superiority or excellence of a product or service as perceived by consumers (Lee et al., 2007, Rigatti-Luchini and Mason, (2010), Song et al., 2014 and Wu et al., 2014). In other words, quality indicates the performance of a product or service (Wu et al., 2014 and Yoon et al., 2010). Crompton and Love (1995)who proposed the first conceptualization to measure festival quality, pointed out that five types of relationships had been used to evaluate quality in tourism, which are as follows: attribute expectations, attribute expectations and importance, attribute performance and importance, attribute performance and expectations, and attribute performance, expectations and importance. They also argued that there are two types of quality: performance (opportunity) and experience. Akhoondnejad (2016) performance quality can be defined as the quality of attributes of a service, which are under the control of the supplier. In contrast to performance quality, experience quality involves both the attributes provided by a supplier and the attributes brought to the opportunity by a visitor.

Akhoondnejad (2016) in the case of festivals, attendees first evaluate the performance quality. Based on the results of this evaluation, the attendees then perceive the experience quality (Cole and Illum 2006). "A festival's performance quality refers to the characteristics of products (including the event design and programmed entertainment, activity, and performance) and services (for example, catering, facilities, merchandising) that are provided at the festival" (Savinovic, Kim, \& Long, 2012, p. 684). Festivals' attributes are the key components in evaluating festivals by attendees. Quality is an important element providing successful tourist experience. Indeed, one of the key strategies for the survival and success of any business is to deliver superior quality to customers (Song et al., 2014, Wong et al., 2014 and Wu et al., 2014). Improving the quality leads to increased visitations and revenues (Yuan \& Jang, 2008). Quality is also recognized as an underpinning element of competitive advantage (Wong et al., 2014 and $\mathrm{Wu}$ et al., 2014). Consequently, festivals have to deliver high quality to their attendees to succeed (Lee, 2014 and Saleh and Ryan, 1993).

\subsection{Satisfaction with Festival}

Satisfaction refers to a consumer's overall evaluation of his/her consumption experience (Kim et al., 2011, Lee and Back, 2008 and Mason and Paggiaro, 2012).Within the customer behavior framework, Hunt (1977) broadly defines consumer satisfaction as a qualitative appraisal of the product experience against what it was supposed to be. Within the discipline of tourism, satisfaction has been defined as an outcome of the tourist' experience in a destination compared against their expectations about the visit (Pizam, Neumann, \& Reichel, 1978). Chon (1989) proposes it as a goodness-of-fit function between tourists' expectations about a destination and the perceived evaluation of the visiting experience. According to the United Nations World Tourism Organization [UNWTO] (1985), customer satisfaction is a psychological concept based on a pleasurable feeling of well-being which arrises when one's expectations about a destination interact with the experience at the destination area.

\subsection{Revisiting Intention of Festival}

Revisiting Intention is defined as "deeply held commitment to rebuy or revisit a preferred product,place, service consistently in the future, despite situational influences and marketing efforts having the potential to cause switching behavior" (Lee \& Back,2008, p. 338). According to Yang et al. (2011), tourists frequently develop an attitude toward a product, place or service, which is based on the evaluations of prior experiences. Based on the attitude, the tourists decide to stay with or leave the product, place or service. Tourist revisiting intentions have favorable behavioral intentions. Behavioral intentions refer to intentions of an individual to perform a particular behavior in the future (Song et al., 2014, Wu et al., 2014 and Yang et al.,2011). They are good predictors of the future behaviors (Kim et al., 2011, Song et al., 2012 and Song et al., 2014). According to Lee et al.,2007, a thirteen-item battery had been developed to measure tourist behavioral intentions.

\subsection{Hypotheses}

There is much empirical research exploring the role of quality in the festival literature. For instance, Baker and Crompton (2000) found that performance quality was a significant determinant of attendee satisfaction and behavioral intentions. Cole and Illum (2006) deduced that performance quality influenced experience quality, which in turn resulted in attendee satisfaction and behavioral intentions. Lee, Petrick, and Crompton (2007) found the significant relationship between festival quality and behavioral intentions. Yuan and Jang (2008) concluded that festival quality significantly predicted satisfaction with festival. Rigatti-Luchini and Mason (2010) found that experiential quality affected 
functional value and revisit intention. Wu et al. 2014 concluded that festival quality had the significant effect on visitor satisfaction and behavioral intentions. Wong et al. (2014) found that festival quality affected attendee satisfaction and revisiting intention. Thus, there appears to be recognition of a significant effect from quality to value, satisfaction and revisiting intention in the literature. Furthermore, it is accepted that quality is a good determinant of trust (Wang et al., 2014).

There is much empirical research investigating the role of satisfaction in the festival literature. For instance, Song et al. (2014) concluded that visitor satisfaction determined visitor trust. Chang et al., (2013) investigated the revisiting intention process of residents and tourists. Their results showed that residents who were satisfied with the festival were more likely to revisit the festival. Kim et al., 2011 and Savinovic et al. (2012) found that visitor satisfaction led to revisit intention. Lee (2014) concluded that attendee satisfaction affected revisit and recommend intentions. Previous research also deduced that attendee satisfaction was a significant predictor of attendee revisiting intention (Baker and Crompton, 2000, Cole and Illum, (2006), Grappi and Montanari, 2011, Lee 2014, Lee et al., 2007, Mason and Paggiaro, 2012, Wu et al., 2014, Yoon et al., 2010 and Yuan and Jang, 2008).

H1: Festival quality has a positive and direct effect on satisfaction with festival.

H2: Festival quality has a positive and direct effect on Tourist behavioral intentions of Festival

H3: Satisfaction with festival has a positive on Tourist behavioral intentions of Festival.

Methodology

2.5. Data Collection Procedure

This research was carried out in Kaohsiung city, Taiwan. The data was collected at the taiwan lantern festival during the early spring of 2016. Domestic tourists who attended the 2016 Kaohsiung lantern festival and were leaving the festival were asked to take part in the survey under the guidance of the researcher. The distribution of the questionnaires was conducted during the late mornings and early evenings at two of three entry and exit points of the Taoyuan station. Since the population of tourists was unknown, convenience sampling method was used. 350 questionnaires were distributed to the tourists. Among the questionnaires obtained from the 334 respondents, 33 ones were incomplete and thereby were eliminated. Finally, 301 questionnaires were usable, resulting in $86 \%$ effective response rate.

\subsection{Measurement Instrument}

A self-administered questionnaire was used to collect empirical data for this research. Based on a comprehensive review of the literature, items for measuring the constructs were extracted and the questionnaire was developed. The questionnaire consisted of two parts. The first part had the questions relating to the demographic characteristics of respondents. The second part had the questions for measuring the items. In the second part, respondents were asked to rate the significance of the items on a five-point Likert scale ( $1=$ completely disagree, $5=$ completely agree $)$.

Festival quality was measured by eight items: product diversity, reasonable prices, professional staff, clean environment, good design, good location, sufficient facilities and well organization, which were taken from $\mathrm{Wu}$ et al. 2014. Satisfaction with festival was measured by three items: right decision, meeting expectations and pleasure, which were taken from previous research (Lee(2014), Mason and Paggiaro,2012 and Wu et al., 2014). Revisit intention were taken from previous research (Baker and Crompton, 2000 and Lee2014).

\subsection{Reliability and Validity of Measurement Scales}

Reliability and validity of the measurement scales were assessed using Cronbach's alpha coefficient and confirmatory factor analysis (CFA), respectively. Reliability is supported if Cronbach's alpha value is 0.7 or above. Validity of the scales was assessed through convergent and discriminant validities. Convergent validity is supported if t-values are more than $|1.96|$ at the alpha $=0.05$ level, standardized factor loadings are above 0.5 , and fit indices of measurement model are as follows: $\chi^{2} / \mathrm{df}$ between 1 and 3, RMSEA <0.08, NFI >0.90, NNFI >0.90, CFI >0.90, IFI >0.90, GFI >0.90, AGFI $>0.90$ and PGFI >0.50. Discriminant validity is supported if chi-square difference between unconstrained and constrained model for all pairs are significant (Vieira, 2011).

As shown in Table 1, the Cronbach's alpha values exceeded the threshold of 0.7, suggesting that the scales had high reliability. Most of the fit indices were within the recommended thresholds, indicating an acceptable fit. T-value and standardized factor loading of all items exceeded the thresholds, supporting the convergent validity. Furthermore, correlations among the constructs were lower than 
0.7, a signal of measure distinctness. A number of CFA models was performed for each pair of the constructs. The results showed that the chi-square differences were significant, supporting the discriminant validity. Thus, reliability and validity of the scales were supported.

Table1. Reliability and Validity of Measurement Scales

\begin{tabular}{|c|c|c|c|c|c|c|}
\hline Construct & Item & Mean (SD) & $\begin{array}{l}\text { Standardized } \\
\text { factor loading }\end{array}$ & Std.error & T-value & Cronbach $\alpha$ \\
\hline \multirow{8}{*}{$\begin{array}{l}\text { Festival } \\
\text { quality }\end{array}$} & Product diversity & $4.18(0.630)$ & 0.60 & 0.034 & 11.07 & 0.891 \\
\hline & Reasonable prices & $3.72(0.768)$ & 0.73 & 0.039 & 14.33 & \\
\hline & Professional staff & $4.41(0.542)$ & 0.68 & 0.028 & 12.94 & \\
\hline & Clean environment & $4.14(0.566)$ & 0.77 & 0.028 & 15.35 & \\
\hline & Good design & $4.36(0.656)$ & 0.73 & 0.033 & 14.34 & \\
\hline & Good location & $4.75(0.360)$ & 0.59 & 0.020 & 10.77 & \\
\hline & Sufficient facilities & $3.92(0.687)$ & 0.82 & 0.033 & 16.94 & \\
\hline & Well organization & $4.27(0.601)$ & 0.84 & 0.029 & 17.66 & \\
\hline \multirow{3}{*}{$\begin{array}{l}\text { Satisfaction } \\
\text { with festival }\end{array}$} & Right decision & $4.30(0.609)$ & 0.83 & 0.030 & 16.92 & 0.822 \\
\hline & $\begin{array}{l}\text { Meeting } \\
\text { expectations }\end{array}$ & $3.84(0.653)$ & 0.80 & 0.033 & 15.89 & \\
\hline & Pleasure & $4.62(0.539)$ & 0.72 & 0.028 & 13.62 & \\
\hline $\begin{array}{l}\text { Behavioral } \\
\text { intentions }\end{array}$ & Revisit intention & $3.76(0.839)$ & 0.75 & 0.043 & 14.60 & 0.855 \\
\hline
\end{tabular}

Fit Indices of Measurement Model: $\chi^{2}=706.32(\mathrm{P}=0.00000), \mathrm{df}=237, \chi^{2} / \mathrm{df}=2.98, \mathrm{RMSEA}=0.081$, NFI=0.95, $\mathrm{NNFI}=0.96, \mathrm{CFI}=0.96, \mathrm{IFI}=0.96, \mathrm{GFI}=0.84, \mathrm{AGFI}=0.79, \mathrm{PGFI}=0.66$.

\section{RESUlTS}

\subsection{Hypotheses Testing}

Path analysis using LISREL 8.8 was conducted to test the hypotheses. The overall fit of the structural model was examined before the assessment of the hypothesized relationships. As shown inTable3, the fit indices indicated that the model was a good fit to the data. In order to support the relationships, the respective $t$-values must be greater than $|1.96|$ at the alpha=0.05 level (Vieira, 2011).

Table2. Hypotheses Testing

\begin{tabular}{|l|l|l|l|l|}
\hline Parameter & Estimate & Std.error & T-value & Result \\
\hline Festival quality $\rightarrow$ Satisfaction with festival & 0.29 & 0.067 & 4.28 & Supported \\
\hline Festival quality $\rightarrow$ Behavioral intentions of festival & -0.072 & 0.077 & -0.94 & Non-supported \\
\hline $\begin{array}{l}\text { Satisfaction with festival } \rightarrow \text { Behavioral intentions of } \\
\text { festival }\end{array}$ & 0.23 & 0.12 & 1.98 & Supported \\
\hline
\end{tabular}

As shown inTable3, the results revealed the positive and direct influence of festival quality had the positive and direct effect on satisfaction $(\gamma=0.29$, $\mathrm{t}$-value $=4.28, \mathrm{p}<0.05)$. Satisfaction with festival significantly affected revisiting intention $(\gamma=0.23$, t-value $=1.98, \mathrm{p}<0.05)$.

\section{Discussion AND CONCLUSION}

Since attendee revisiting intention is needed for festivals' success, it is vital to know which factors may influence it. Understanding the predictors of attendee revisiting intention provides information for festival managers to prioritize their tasks and organize their festivals so that the festivals can better build revisiting intention in attendees. Therefore, this research proposed a comprehensive model of 
attendee revisiting intention at a local festival. More specifically, the research tested the effects of festival quality, satisfaction and revisiting intention to a given festival. The research also tested the relationships among the predictors. Applying structural equation modeling (SEM), the model was empirically tested on a sample of 301 domestic tourists.

This research had important theoretical implications. The findings enriched the festival literature in several ways. First, the research focused on large-scale festival, which had seldom been addressed. Second, the research developed a more comprehensive model of attendee revisiting intention than any previous research.

Besides theoretical implications, the findings provided several managerial implications for festival managers. Festival managers must strive to build revisiting intention in attendees, because attendee revisiting intention is recognized as a major factor to succeed. As the findings suggested that satisfaction were significant predictors of revisiting intention, the managers can conduct their festivals in a way which the festivals deliver superior value to attendees, satisfy their needs and wants, and gain their revisiting intention. Satisfaction can be enhanced by providing various products to meet the expectations and needs of a wide variety of attendees. Offering satisfactory experiences is another way to strengthen the relationships with attendees. To do so, the findings suggested that festival managers can focus their resources on enhancing perceived quality.

As with any research, the current research had several limitations which must be noted. First, the research was limited to one country of one region. Second, the research was limited to a small-scale and one type of festival. Third, the research focused on domestic tourists. Hence, the findings may not be applied to festivals in other regions, of different scales, and of different types. Therefore, future research should be conducted in other regions, scales, and types and focus on international tourists. Fourth, convenience sampling method was used to collect the data. Since a convenience sample does not represent the entire population, a correct sampling method should be used in future research. Fifth, although this research proposed a comprehensive model examining the relationships among festival quality, satisfaction, and revisiting intention, the research ignored some other constructs. Therefore, future research is encouraged to include the other predictors of attendee revisiting intention in the model. Sixth, the indirect effects of the construct were not examined.

\section{REFERENCES}

[1] Akhoondnejad, A (2016). Tourist loyalty to a local cultural event: The case of Turkmen handicrafts festiva. Tourism Management, 52, 468-477

[2] Baker, D. A., \& Crompton, J. L. (2000). Quality, satisfaction and behavioral intentions. Annals of Tourism Research, 27(3), 785-804.

[3] Chang, J. (2006). Segmenting tourists to aboriginal cultural festivals: an example in the Rukai tribal area, Taiwan. Tourism Management, 27, 1224-1234.

[4] Chang, S., Gibson, H., \& Sission, L. (2013). The loyalty process of residents and tourists in the festival context. Current Issues in Tourism, 17(9), 783-799.

[5] Chon, K. (1989). Understanding recreational travellers' motivation, attitude and satisfaction. Tourist Review, 44, 3e7

[6] Cole, S. T., \& Illum, S. F. (2006). Examining the mediating role of festival visitors' satisfaction in the relationship between service quality and behavioral intentions. Journal of Vacation Marketing, 12(2), 160-173.

[7] Crompton, J. L., \& Love, L. L. (1995). The predictive validity of alternative approaches to evaluating quality of a festival. Journal of Travel Research, 34(1), 11-24.

[8] Getz, D. (2008). Event tourism: definition, evolution, and research. Tourism Management, 29, 403-428.

[9] Grappi, S., \& Montanari, F. (2011). The role of social identification and hedonism in affecting tourist re-patronizing behaviours: the case of an Italian festival. Tourism Management, 32, $1128-1140$.

[10] Gursoy, D., Spangenberg, E. R., \& Rutherford, D. G. (2006). The hedonic and utilitarian dimensions of attendees' attitudes toward festivals. Journal of Hospitality \& Tourism Research, 30(3), 279-294.

[11] Hunt, K. (1977). Conceptualization and measurement of consumer satisfaction and Dissatisfaction. Cambridge: Marketing Science Institute.

[12] Kim, Y. H., Kim, M., \& Goh, B. K. (2011). An examination of food tourist's behavior: using the modified theory of reasoned action. Tourism Management, 32, 1159-1165.

International Journal of Research in Tourism and Hospitality (IJRTH) 
[13] Lee, J. (2014). Visitors' emotional responses to the festival environment. Journal of Travel \& Tourism Marketing, 31(1), 114-131.

[14] Lee, J.-S., \& Back, K.-J. (2008). Attendee-based brand equity. Tourism Management, 29, 331-344.

[15] Lee, S. Y., Petrick, J. F., \& Crompton, J. (2007). The roles of quality and intermediary constructs in determining festival attendees behavioral intention. Journal of Travel Research, 45(4), 402-412.

[16] Mason, M. C., \& Paggiaro, A. (2012). Investigating the role of festival scape in culinary tourism: the case of food and wine events. Tourism Management, 33(6), 1329-1336.

[17] Pizam, A., Neumann, Y., \& Reichel, A. (1978). Dimensions of tourist satisfaction with a destination area. Annals of Tourism Research, 5, 314-322.

[18] Rigatti-Luchini, S., \& Mason, M. C. (2010). An empirical assessment of the effects of quality, value and customer satisfaction on consumer behavioral intentions in food events. International Journal of Event Management Research, 5(1), 46-61.

[19] Saleh, F., \& Ryan, C. (1993). Jazz and knitwear: factors that attract tourists to festivals. Tourism Management, 14(4), 289-297.

[20] Savinovic, A., Kim, S., \& Long, P. (2012). Audience members' motivation, satisfaction, and intention to revisit: an ethnic minority cultural festival. Journal of Travel \& Tourism Marketing, 29(7), 682-694.

[21] Shen, S. (2014). Intention to revisit traditional folk events: a case study of Qinhuai Lantern Festival, China. International Journal of Tourism Research, 16(5), 513-520.

[22] Song, H.-J., Lee, C.-K., Kim, M., Bendle, L. J., \& Shin, C. Y. (2014a). Investigating relationships among festival quality, satisfaction, trust, and support: the case of an oriental medicine festival. Journal of Travel \& Tourism Marketing, 31(2), 211-228.

[23] Song, H.-J., You, H.-J., Reisinger, Y., Lee, C.-K., \& Lee, S.-K. (2014b). Behavioral intention of visitors to an oriental medicine festival: an extended model of goal directed behavior. Tourism Management, 42, 101-113.

[24] Vieira, A. L. (2011). Interactive LISREL in practice: Getting started with a SIMPLIS approach. Berlin: Springer.

[25] UNWTO. (1985). Identification and evaluation of those components of tourism services which have a bearing on tourist satisfaction and which can be regulated, and state measures to ensure adequate quality of tourism services. Madrid: World Tourism Organization

[26] Wang, L., Law, R., Hung, K., \& Guillet, B. D. (2014). Consumer trust in tourism and hospitality: a review of the literature. Journal of Hospitality and Tourism Management, 21, 1-9.

[27] Weber, K., \& Ali-Knight, J. (2012). Events and festivals in Asia and the Middle East/ North Africa (MENA) region. International Journal of Event and Festival Management, 3(1), 4-8.

[28] Wong, J., Wu, H.-C., \& Cheng, C.-C. (2014). An empirical analysis of synthesizing the effects of festival quality, emotion, festival image and festival satisfaction on festival loyalty: a case study of Macau food festival. International Journal of Tourism Research, X(X), 1-16.

[29] Wu, H.-C., Wong, J. W.-C., \& Cheng, C.-C. (2014). An empirical study of behavioral intentions in the food festival: the case of Macau. Asia Pacific Journal of Tourism Research, 19(11), 1278-1305.

[30] Yang, J., Yingkang, Y., \& Cen, J. (2011). Festival tourists' emotion, perceived value, and behavioral intentions: a test of the moderating effect of festivals cape. Journal of Convention \& Event Tourism, 12(1), 25-44.

[31] Yoon, Y.-S., Lee, J.-S., \& Lee, C.-K. (2010). Measuring festival quality and value affecting visitors' satisfaction and loyalty using a structural approach. International Journal of Hospitality Management, 29, 335-342.

[32] Yuan, J., \& Jang, S. (2008). The effects of quality and satisfaction on awareness and behavioral intentions: exploring the role of a wine festival. Journal of Travel Research, 46, 279-288. 